\title{
Valley of the Wolves-Iraq: Anti-Geopolitics Alla Turca
}

\author{
Lerna K. Yanık \\ Bilkent University
}

\begin{abstract}
This article discusses the Turkish movie Valley of the Wolves-Iraq (Kurtlar Vadisi-Irak), a blockbuster in Turkey in 2006. The movie has made an important mark on the history of Turkish popular culture, not through any artistic achievement, but because of the movie's 'reversed' representations/imaginations. The movie contains favorable views of 'Pax Turca' and 'Pax Islamica' as well as a critique, which is quite anti-American, of the American occupation of Iraq. These images and thus the movie itself give powerful insights into the geopolitical self/other representations of Turks in the current global (dis)order. In addition to these 'reversed' geopolitical representations, the movie reverses (or to be more correct, 'steals') and uses one of the most important soft power tools that Westerners have: cinema and, hence, makes Valley of the WolvesIraq a case of double 'anti-geopolitics'.
\end{abstract}

\section{Keywords}

Valley of the Wolves-Iraq, anti-geopolitics, Turkey, popular culture, nationalism, cinema

The movie Valley of the Wolves-Iraq (Kurtlar Vadisi-Irak) was not only the 'hit' movie of 2006 in Turkey, but it was credited with several firsts in the history of Turkish cinema: it was the most expensive Turkish movie ever made, one of the most-watched Turkish movie of all time, and because of its anti-American, anti-Western and anti-Semitic character, the only Turkish film that further strained (the already strained) US-Turkish relations. In addition to all these, Valley of the Wolves-Iraq will probably be remembered as the only Turkish movie, according to the Turkish newspaper Hürriyet, that became the subject of a question at a hearing in the US Congress when, in March 2006, US Secretary of State Condoleezza Rice was asked why moviegoers in Turkey, a supposedly 'staunch' US ally, had welcomed Valley of the Wolves-Iraq 'that portrayed the US soldiers as villains killing innocent people at a wedding in Iraq,' and what the Bush administration was doing in order to win the 'hearts and the minds of the Muslim world' (Hürriyet 2006). 
The battle for 'hearts and the minds' was important in the past; today, it is considered as important as the battle itself. Winning 'hearts and minds' is important because it is considered the 'key' to 'getting the outcomes wanted' without 'coercion,' but rather by way of 'attraction' (Nye 2004: x). And, it is no coincidence that Valley of the Wolves-Iraq appeared on the silver screen immediately after various observers started to talk about American soft power reaching new lows, and anti-Americanism, not only in Turkey, but around the world reaching new highs (Kurlantzick 2005).

This article discusses the uproar - domestic and international - that Valley of the Wolves-Iraq created. The movie is a spin-off from a popular TV series of the same name (Kurtlar Vadisi), and details the adventures of a Rambo/Bond mix Turkish secret-service agent and his friends in American-invaded Iraq in their quest to take revenge for Turkish soldiers who were captured and humiliated by American soldiers. The uproar that the movie created, however, is due to the out-of-the ordinary geopolitical representations/imaginations of Turkey, Iraq, and the Middle East as well as the Americans. I argue that these representations/imaginations in Valley of the Wolves-Iraq are 'reversed' geopolitical representations or anti-geopolitics, to use the critical geopolitics language. Anti-geopolitics is the attempt of lesser powers to defy the world's hegemon. This defiance can take material and non-material forms: the lesser powers can come up with their own economic and military might as well as their own versions of representations of the world or both (Routledge 1998: 245).

As I will elaborate shortly, Valley of the Wolves-Iraq contains an idealized representation of Islam, Turkish presence in the Middle East and a very negative view of Americans and the United States. While the movie portrays Islam and Turkish presence in the Middle East as elements of peace and stability, the Americans are portrayed as religious zealots trying to bring their own version of 'order' to Babylon and thus destabilizing the supposed order in the Middle East. Given this framework, in a nutshell, the movie can be described as the clash of 'Pax Turca' along with 'Pax Islamica', against the American Empire.

As a movie, Valley of the Wolves-Iraq does not achieve much in terms of artistry. But through its 'reversed' representations, it becomes one of the finest examples of anti-geopolitics producing representations running contrary to the predominant geopolitical representations coming out of Hollywood, which, most of the time, portray Americans as the 'good guys' and the rest of the world as the 'bad guys.' What is more, in Valley of the Wolves-Iraq not only are the representations reversed, but there is the use of a soft power tool, i.e. cinema, as well. That is, on the screen, Valley of the Wolves-Iraq shows that Turkish secret-service agents can beat the American ones and off the screen, Turks can (at least try to) compete with the American monopoly of producing 
representations of the world. The movie's producers have expressed their sense of mission in this regard as well. The scriptwriter, Bahadır Özdener, for example, said 'perhaps $60 \%$ or $70 \%$ of what happens on screen is factually true. Turkey and America are allies, but Turkey wants to say something to its friend. We want to say the bitter truth. We want to say that this is wrong' (Rainsford 2006). So, no matter how anti-American, anti-Western and anti-Semitic (and thus politically incorrect) by Western standards, Valley of the Wolves-Iraq can be read as a Turkish popular geopolitical critique of the American readings of both the 'reel' and the real world.

Popular geopolitics is one of the most important tools used to understand perceptions regarding national and international images that exist and persist in society (Dittmer 2005; Edwardson 2003). As part of popular geopolitics, movies and their characters have an important role in the expression and reproduction of a nation's or state's position in the international order, through rewriting of the space and reevaluating global politics (O’Tuathail 2005; Dodds 2000; Dodds 2003; Power and Crampton 2005). And if critical geopolitics is about the 'competition' to 'impose order and meaning upon space,' as O'Tuathail (1996: 1) argues, then Valley of the Wolves-Iraq has created the Turkish 'impositions' of representations over the current state of affairs in the Middle East and Turkey's place in this (dis)order.

\section{The Movie, the Context, and the Responses}

\section{The Movie}

'Those that think of their end cannot become a hero', says the Valley of the Wolves-Iraq's tagline. The hero of the movie, Polat Alemdar, played by Necati Şaşmaz, who previously was also the hero of the TV series in Turkey, obviously not thinking about himself or his end, jumps from the TV screen to the silver screen with two of his friends, Memati Baş and Abdulhey Çoban, to find himself in Northern Iraq. The 'good guys' mission is to take fictional revenge on a non-fictional incident - the hooded capturing of the Turkish Special Forces in Northern Iraq on July 4, 2003 by US troops. ${ }^{1}$ From that point, the movie

1 Though the reason for this hooded capturing was never made public there were allegations suggesting that the Turks who were arrested were part of a conspiracy plan involving the assassination of the mayor of Kirkuk. See for example, Michael Howard and Suzanne Goldenberg, 'US Arrest of Soldiers Infuriates Turkey', The Guardian, July 8, 2003. 
turns into a cat-and-mouse game, in which Alemdar and his friends try to catch the 'bad guy' named Sam Marshall (played by Billy Zane), the American commander who is responsible for the capturing of the Turkish special forces, in Valley of the Wolves-Iraq.

The character Sam Marshall is no ordinary American soldier. As his name indicates, he is the embodiment of the United States of America, i.e. Uncle Sam and the self-appointed marshal of the world (Erdoğan 2006: 89) - two references embedded in one name, with a last name highlighting American unilateralism and hegemony. And, not surprisingly, just like the Bush administration, Sam Marshall believes that he is on a peacemaking mission in 'Babylon' fulfilling the orders of God.

The paths of these two characters cross after Marshall arrests, hoods, and thus humiliates Turkish soldiers, prompting Alemdar and his friends' arrival in Iraq to settle the account. The 'good guys' first plan to find, hood, and thus settle the account with Sam Marshall fails at the American hotel, the Grand Harilton, (the scriptwriters seemed to be inspired by the Hilton when it came to name selection), when Sam Marshall artfully uses school children as a trump card outdoing Alemdar and his friends.

After this failed attempt, the issue between Alemdar and Marshall is no longer a matter of settling scores, but turns into a deadly hunt. In the course of this chase, another avenger, Leyla, the unfortunate bride, joins Alemdar and his friends. The viewer learns in the opening scenes of the movie that Leyla's husband-to-be, along with many of the guests, was killed by Sam Marshall's troops, when Marshall's troops raided their wedding party on the grounds that guests firing shots in celebration of the wedding (a tradition in the Middle East) were 'terrorists.' So, in addition to the Hood Incident, in Suleymaniah, the scriptwriters were also (slightly) inspired by another real event: the July 2002 bombing of a wedding celebration near Oruzgan, Afghanistan by US fighter jets. Though Valley of the Wolves-Iraq's starting point is two real events, the Hood Incident and Wedding Bombing, the rest of the movie is also sprinkled with remakes of the scenes of violence from the war in Iraq that the world's media has written about. These scenes are shot in the style of a documentary so as to better mix fiction with some doses of reality: torture in $\mathrm{Abu}$ Ghraib, extrajudicial killing of civilians, suicide bombers, American soldiers searching homes and brutally beating people, Turkomans and Arabs packing their things and leaving their homes and lands.

There are 'good guys' and 'bad guys' in Valley of the Wolves-Iraq, just like in any standard action movie. The 'good guys' are the Turks, the Turkomans and the Arabs of Northern Iraq. The 'bad guys' are the Americans, the Jews, evangelical Christians, and the Kurds of Iraq, who are collaborating with the 
Americans. The movie is like a typical American action movie from the 1970 s and the 1980s. The main 'good guy' is a hybrid between Rambo and Bond; the characters are caricaturized and the plot is sketchy, but the stereotypes and representations are reversed. Of course, like most action movies, it ends, with the 'good guys' winning. Though, in the final scene, one of the 'good guys', the unfortunate bride Leyla, is killed; nevertheless, in this last scene, Polat Alemdar thrusts Leyla's family heirloom dagger into Sam Marshall's chest and kills him. Hence, Alemdar gets revenge for Leyla, the Turkish soldiers (Cheviron 2006; Sağlam 2006; Coşkun 2006) and as some commentators have argued, also an unmentioned revenge: the revenge of the Midnight Express ${ }^{2}$ (Tugend 2006; Baran: 138).

Overall, the movie Valley of the Wolves-Iraq becomes a revenge taking mechanism, in all realms, but more importantly, in the realm of creating 'reversed' geopolitical representations. As one Washington Post article quoting a Turkish moviegoer puts it, in the 'popular culture wars,' Valley of the WolvesIraq is 'a missile fired from the Turkish side' (Vick 2006). Coupled with the reversal of stereotypes and representations, the movie's popularity, ${ }^{3}$ on the other hand was regarded as 'concrete' evidence of rabid 'anti-Americanism' in Turkey (Geraghty 2006; Musa 2006; Birch 2006; Baran 2006; Rainsford 2006). A commentator of Turkish origin even expressed her 'shock and disgust' with the portrayal of Americans as 'pure evil,' worrying that the 'paranoid fears propagated' would sooner or later become 'government policy' (Baran 2006: 138). For some Turks, on the other hand, the movie was nothing but a ploy to soothe and depressurize anti-American sentiment in Turkey (Yaşın 2006: 158). However, those who hastily jumped to the 'anti-Americanism in Turkey' conclusion failed to consider the context and reasons for the popularity of the movie and paid scant attention to contextual factors. Reviewing these factors may show the reader why analyzing Valley of the Wolves-Iraq as a case of anti-geopolitics is a noteworthy endeavor to pursue.

\section{The Context}

First of all, Valley of the Wolves-Iraq is a sequel to the very popular TV series Kurtlar Vadisi - that ran on Turkish television. In the TV series, the same

2 The 1978 movie was about an American who got caught while trying to smuggle hashish out of Turkey. It portrayed Turks as 'villains' mistreating foreigners in prison and, eventually, the movie came to be equated with anti-Turkishness.

${ }^{3}$ In Turkey, within a month of its opening, approximately four million moviegoers saw Valley of the Wolves-Iraq. 'Kurtlar Vadisi Irak 1 Ayda Gora'nın Rekorunu Kırdı', Milliyet, March 7, 2006. 
main character, Polat Alemdar, had infiltrated the Turkish mafia for the good of the country, causing the eventual collapse and the dissolution of it. The values of honor, duty, and love of country coming before anything else, as well as other nationalist symbols were widely used in the TV series (Gültekin 2006; Erol Işık 2006), creating a large group of fans in Turkey. By the time the movie was made, the character of Polat Alemdar had become an idol, and the movie further boosted this idolizing. In 2006, for example, when Turkish high schools kids were asked who their role model was, 19.4 per cent of the surveyed answered Polat Alemdar (Vatan 2006).

Secondly, it is important to note that Valley of the Wolves-Iraq, by and large, was a commercial enterprise with sponsors and an extensive marketing campaign. Having spent 10 million dollars and touting it as the most expensive movie made in the history of Turkish cinema, the movie's producers made sure that Valley of the Wolves-Iraq would not be a box-office flop. The sponsors of the movie, for instance, make themselves apparent in the very first scenes of the movie: Hürriyet, a Turkish mainstream newspaper and Next Star, a satellite dish company. Marketing tricks, on the other hand, included offering a private screening to the Turkish Prime Minister Recep Tayyip Erdoğan before anyone else had seen the movie (Haber X 2006), inviting his wife and some other ministers to the gala of the movie, and ensuring that favorable reviews these people made were known to the public - a message that was successfully conveyed by the Turkish media (Hasan 2006).

Thirdly, the producers and marketers of Valley of the Wolves-Iraq could not have chosen a better time, when the nationalistic sentiments were running high in Turkey and had just started resonating in the realm of popular culture. Nationalism has run high in Turkey at most times, but the latest wave of 'rising nationalism' of the past few years is attributed to two main issues: the reemergence of Kurdish nationalism along with the Kurdish separatist attacks, and Turkey's rocky relationship with the European Union (EU). The Kurdish separatist group, the PKK (Partiya Karkaren Kurdistan) has found a safe haven in American occupied Northern Iraq, and the ruled and rulers in Turkey have come to blame the United States for the resurrection of Kurdish separatism in Turkey since the summer of 2004. In addition to Kurdish nationalism, Turkey's rocky relationship with the EU has also contributed to this rising nationalism in Turkey. The fact that while Turkey has endeavored to become an EU member for more than four decades, countries that only became independent after the end of the Cold War have since become EU members, has created resentment among Turks. What is more, the EU's demands for democratization, improvement of minority rights, etc. have come to be regarded as Westernoriginating conspiracies to weaken and divide Turkey. All these developments 
have created alienated masses in Turkey, which in turn have come to look for a way to deal with the problems that they believe have been created by the West.

Popular culture has been the venue not only for expressing and reflecting alienated Turks' anger, but also replenishing the tarnished national ego. In the past few years, semi-fictional novels have captured the best-seller lists in Turkey for months. Şu Çılgın Türkler (Those Crazy Turks) and Metal Fırtına (Metal Storm) and its sequels are cases in point. Şu Çılgın Türkler depicts the gallantry of the Turks in the War of Liberation. The Metal Storm, ${ }^{4}$ on the other hand, published in 2004, tells the story of a Turkish-American war in 2007, in which, not surprisingly, Turkish troops defeat the American ones and thus foil American plans to invade Turkey. The storylines of these books, just like Valley of the Wolves-Iraq, mix fiction with fact and thus blur the lines between what is real and unreal. Moreover, these semi-fictional novels equate these wars with the present-day 'struggle' that Turks have with the West (Yanık 2008). Looking at Valley of the Wolves-Iraq in this context, basing it on a real event such as the Hood Incident, and then scattering the movie with remakes of real events in documentary style, such as the torture in Abu Ghraib, brutality of the American forces, etc., the producers of the movie ably exploited the revenge, honor and love of country motif - the classic staples for war and action movies. In other words, Valley of the Wolves-Iraq successfully managed to cash in on this supposed Western insult and nationalistic sentiments running wild in Turkish society.

\section{The Responses}

The responses to Valley of the Wolves-Iraq were as interesting as the context from which the movie stemmed. As a blockbuster, in addition to Turkey, it received coverage in various countries, ranging from the United States to Germany and from Russia to Argentina. The first interesting comment came from the producers of the movie. When faced with accusations of antiAmericanism, anti-Semitism, and anti-Christianism, they replied that Valley of the Wolves-Iraq 'was neither an anti-American nor an anti-Semitic movie, but an anti-war movie' (Bağrıaçık 2006).

4 Burak Turna and Orkun Uçar, Metal Fırtına (Istanbul: Timaş Yayınları, 2004). This political fiction as its authors like to call it, used real names as well as some military information that according to the United States, only Turkish Ministry of Foreign Affairs and the Army Chief of Staff would have known. Turna and Uçar also wrote several other sequels to the first Metal Firtına book. 
American officials preferred not to discuss the movie, saying that it was 'fictitious' (Schogol 2006). Nevertheless, they warned US soldiers stationed in countries where the movie was showing to stay away from movie theaters and to avoid discussing the movie with strangers (Murray 2006). One covert criticism that was made public came from General James Jones who said 'what is important is to separate truth from fiction and to help people base their opinions on truths and facts. What is important is not inciting feelings in a certain direction' (Turkish Daily News 2006). However, American officials expressed that they felt uneasy with the way Turkish elites embraced the movie. One American official, who wanted to remain anonymous, was quoted as saying 'can you imagine the First Lady or the head of the House of Representatives going to the gala performance of a film that could incite anti-Turkish feeling among Americans?' (Birch 2006).

American actors Billy Zane and Gary Busey got their share of bad press as well. They were criticized for taking part 'in the vilest propaganda for some Turkish lira' (Geraghty 2006). Some conservative critics even suggested that these two actors should be boycotted for 'defaming American soldiers, portraying [them as].... evil, brutal, cold-hearted murderers' (Schlussel 2006). These critics were not only bothered by the level of anti-Americanism, but also with the anti-Semitism in the movie. Gary Busey's Jewish doctor character, who was harvesting organs from Iraqi prisoners and shipping them abroad, was considered not only a sign of anti-Semitism, but also of 'revival of the ancient blood libel against the Jews' (Schlussel 2006; Tugend 2006).

The Turkish political elites, on the other hand, seemed quite sure that the movie would have no effect on Turkish-American relations. The Minister of Foreign Affairs at the time, Abdullah Gül, said 'the Americans and Europeans make movies of this sort. Compared to the movies made in the past few years in the United States, this movie is nothing' (Zaman 2006). Turkish Ambassador to the United States, Nebi Şensoy, on the other hand, said that the movie was not a 'problem' between the United States and Turkey, but rather, was a 'hiccup' (Milliyet 2006). Yet Valley of the Wolves-Iraq continued to irritate people in the United States even two years after its release. In March 2008, for example, Turkish newspapers reported that one of Hillary Clinton's election campaign fundraisers was removed from her staff on the grounds that he financed the making of Valley of the Wolves_Iraq (Internet Haber 2008).

In Germany, there were mixed reactions to the movie. Christian Social Union leader and Bavarian Prime Minister Edmund Stoiber was extremely critical of Valley of the Wolves-Iraq. He, along with the Jewish community in Germany, asked for the movie to be banned (Çalabakan 2006; Agence France Press 2006), but to no avail. Other German officials did not feel the same way. 
Silvana Koch-Mehrin, a member of the European Parliament, criticized the demand to the ban the movie (Çalabakan, Oruç and Çiftçi 2006). And, when one of the movie theater chains in Germany, despite the increased public demand to watch Valley of the Wolves-Iraq, did not extend the movie's showing, the chain was applauded for 'social responsibility' (Germany - OSC Report 2006).

What is more, according to Turkish newspapers, Valley of the Wolves-Iraq made headlines in countries where there is little or no Turkish population. The common theme in these news stories is that the Turks were presented as getting even with Hollywood. One Argentinean newspaper mentioned the movie as 'this time Rambo is Turkish, victims are Yankees' (Çiftçi 2006). One of the TV channels in Russia sent a crew to interview Turks about the movie, and presented the movie in their news hour as 'Turks' answer to Hollywood' (Turk Rus 2006), and, again in Russia, the movie was selected to compete in the International Muslim Cinema Festival (Başlamış, 2006). Even Hizb ut-Tahrir of Britain felt the need to comment on Valley of the Wolves-Iraq, saying that the popularity of the movie showed that Turks wanted to revive the seat of the Caliphate and also find hope in Islam (Members of Hizb ut-Tahrir 2006). It seems difficult to understand how Hizb ut-Tahrir arrived at that conclusion, but the torrent of responses from various parties amplified the attention that was given to the movie. But, it was the anti-geopolitical content about the Middle East, Turkey, and the Americans that unleashed these responses.

\section{When 'Pax Turca' and 'Pax Islamica' Meet the American Empire}

Campbell argues that a state's identity is dependent on the 'reproduction' of 'representations' of 'border,' 'threat,' and 'danger.' He believes that these 'reproductions' can be achieved in contexts, what he calls the 'cultural discourses of community,' which can be thought of as free from state interference (Campbell 2003: 57). Yet, since the outcome of the 'reproduction of these representations' is eventually related to the making of a state's identity, no discourse, regardless of how free from state interference it is, can be thought of as dissociated from a state's identity (ibid.).

Valley of the Wolves-Iraq neatly fits this description by Campbell and other students of critical geopolitics. Valley of the Wolves-Iraq is a commercial and supposedly artistic enterprise. Yet deliberately or not it also produces representations of not only the Turkish state and history, but also of Middle Eastern geography and politics as well as representations of the United States of America. Starting from the first scene of the movie, viewers are imbued with 
the Turkish version of these representations. The scene opens with a Turkish soldier, Süleyman, writing a letter - a suicide note, as viewers will understand in a few seconds - to a 'Dear Brother.' This 'Dear Brother' is none other than Polat Alemdar. The soldier's story or the event that prompted him to write the letter to Alemdar, is told with flashbacks and is based on a real event: the hooded capturing of the Turkish special troops on July 4, 2003 in Suleymaniah, Northern Iraq.

'On July 4th, while we are in Suleymaniah serving the security of the region, these men who, just a couple of days ago, drunk our tea, who we fought together, raided us and pointed their guns at us,' writes this Turkish soldier in his note to Alemdar. Then the scene moves to another flashback, where the commander of the Turkish troops is reporting the American raid to his superiors on the phone. Despite the repeated assurances of this Turkish commander that the attack is not against them, but against the 'Turkish nation' and that he and his men are 'ready to die,' these 'unknown' superiors on the phone insist that the Turkish special troops should not resist arrest. Eventually, without firing a single shot, the Turks surrender to Sam Marshall's troops. As they do so, Marshall attempts to touch the Turkish flag on the table, but one of the Turks in the room quickly snatches the flag and puts it in his pocket. At that moment, the viewer realizes that the person who picks up the flag is the very same soldier writing this note to his 'Dear Brother.' What the viewer is also shown is that the American commander Marshall is not just humiliating Turkish soldiers by arresting them, but also insulting the Turkish nation when he tries to touch the Turkish flag. Then, as the members of the Turkish special troops are being arrested, Sam Marshall jokingly tells his troops to make sure that the Turkish soldiers are hooded so that Americans 'do not toy with their honor.' Then the camera zooms back to the soldier writing final lines of his suicide note. Before committing suicide, the soldier finishes up by saying:

SÜLEYMAN: For all this time that we were in Iraq, we asked ourselves: what business did we have here? Over time we realized that those who conquered these lands always tormented the people on it. Only our ancestors did not do this. And, that day we did not live up to the legacy of our ancestors. That day we could not die for justice, stop the torment, we could not die for our honor.... And now, I want this from you. How painful it is, isn't it?

This opening scene of Valley of the Wolves-Iraq provides a condensed version of the series of representations that are to come in the movie. Honor, duty, and love of country - three amorphous feelings related to the good of a nation - dominate this very first scene of the movie. Turks are shown as a nation of people sacrificing their own lives for those values. What is more, Turkish historical legacy, i.e. the Ottoman presence in Iraq (and to some extent 
in the Middle East), which is quite controversial indeed, is also favorably presented. As a result of Valley of the Wolves-Iraq's idealized representations of Turkish history, a Turkish soldier, who is about to commit suicide, can talk about the 'justice,' 'stability,' and 'order' that the Ottoman Empire brought to the region. Moreover, in the rest of the movie, the Iraqis are portrayed as being extremely welcoming to the Turks. For example, the movie contains scenes such as kids playing on the street yelling 'Turkey,' or an old man saying 'Mashallah' when he hears that Polat Alemdar comes from Turkey. Such scenes not only portray Turkish presence and history in a positive way, but also make 'Pax Turca', i.e. stability and order provided by the Turkish Empire, one of the most important themes running through Valley of the Wolves-Iraq.

Paradoxically, as much as there is glorification of - and thus a tacit yearning for the 'golden past' - one can also read a critique of the 'gloomy present' in the movie, i.e. the current state of affairs in Turkey (Erdoğan 2006: 83). Turkish characters never pronounce these criticisms, but the viewer is shown the unspoken version of them. The unknown superiors, who, on the phone, give the Turkish special troops in Suleymaniah the order to not resist, is one such example that can be read as a critique of the Turkish state. Because the state cannot do its job, Polat Alemdar and his friends are called on to save the honor of the nation and fill in for the state that looks unwilling or incapable of doing so.

The in-service-for-the-good-of-the-nation theme is repeated in the scene at the Grand Harilton where Alemdar 'invites' Sam Marshall and his men to be hooded and their pictures to be taken by journalists. Alemdar tells Marshall, 'I am not a political party leader. Nor am I diplomat, or a statesman. As you just said, I am a Turk.' By saying this, the Alemdar character shows that he, as a Turk, was there to hood Marshall because the state was absent and incapable of doing so. This is what Sharp calls 'feminization of government' (Sharp 1998: 165). But, this time, what we are seeing is not the feminization of the government, but of the state. This scene in Valley of the Wolves-Iraq portrays a state that is not 'man' enough to stand up against the American troops and save the 'honor' of the nation.

Although Polat Alemdar is there to save the honor of the nation, he still respects the state. So presenting the 'gloomy present' is done by the 'bad guy', Sam Marshall. Marshall is very critical of the state of affairs in modern-day Turkey; he is specifically shown making fun of Turkey's dependence on the United States:

MARSHALL: Look Turk......you love to brag, you have your own rules and you have unchanging Iraq policies and red lines. You always say no one can do anything here. Let me tell you something: we screwed up your Iraq policy and 
your red lines. I do not understand you. You are not mad at [us doing all] this but at these hoods. We sent you money; we even sent the waistbands for your underwear. Why can you not produce anything? You say 'money', we send it. Do you swindle each other, so that you can get more? You said 'we want arms', we sent them. You accepted to fight. And then asked for more money. How can you forget that you begged us to protect you from the Communists? I will tell you what drove you mad: we do not need you anymore.

Marshall's comments are indeed a tongue-in-cheek summary of Turkish political history since the end of World War II: Turkey was a buffer state during the Cold War, but now that Soviet threat is gone and Turkey is no longer geopolitically important - a nightmare scenario for Turkish policy makers (Yaşın: 165). On top of the loss of importance, the country is suffering from corruption or as the 'bad guy' puts it, 'Turks [are] swindling each other.'

While the Turks are rosily portrayed in Valley of Wolves-Iraq, Americans, on the other hand, are shown through a very critical lens. Through the persona of Sam Marshall, the Americans are portrayed as an extremely hypocritical exally betraying the Turks, by saying one thing and doing just the opposite, and working to divide Iraq so they can benefit from its riches. Sam Marshall's whistling tune is a case in point, indicative of this hypocrisy. In almost every scene of the movie, the Marshall character, who in reality has a hardcore divide and rule agenda, whistles or plays the Ode to Joy (which also is the anthem of the European Union), the lyrics of which are about all people becoming brothers.

Additionally, several different scenes highlight another theme that runs through the movie: the American intentions of benefiting from Iraq's riches. When Alemdar and his friends first arrive at the Grand Harilton, Alemdar asks the hotel manager to find Sam Marshall. When the hotel manager looks puzzled, pretending not to know Marshall's whereabouts, Alemdar asks, 'Are you not the one who pays his salary?' After Alemdar's question comes the punch line of the scene linking American expansionism/ hegemony/imperialism to American capitalism: 'Is not American capitalism boss of the American soldiers?' This theme is reiterated when the Turkoman leader complains to Alemdar about the way the Americans divided up Iraq. The leader says, "[the Americans] gave the desert to Arabs, mountains to Kurds and kept oil for themselves and we do not have any place to go.'

As stated above, the viewer is also reminded of American brutality in Iraq, such as the torture and torment at Abu Ghraib, with several different scenes of American soldiers (men and women - a reference probably to Lynndie England, the infamous female torturer of Abu Ghraib prison) torturing the Iraqis inserted in the movie. The scenes' documentary style tries to make the movie's storyline appear more real. 
Again using the persona of Sam Marshall, Americans are portrayed as fundamentalist Christians talking to God and believing that they are on a religious mission in Babylon, i.e. the Promised Land. Several scenes and dialogs are telling in this regard and it was partially dialogs by Marshall that prompted critics to label Valley of the Wolves-Iraq as an anti-Christian movie:

MARSHALL: The difference is that you act with your feelings. I am here to provide peace. And, those who can make peace are God's children.

ALEMDAR: I do not have a child like you.

MARSHALL (praying after barely surviving an assassination attempt): Why do not you want me near you? But I know my duties for you have not finished yet ....I will die in these lands, my blood will flow in these lands, until the promised moment, that is until your return, that is until the promised land is ours, my blood will flow and when the promised land is ours peace will arrive. And whoever makes peace will be God's Child.

Throughout history, religion has functioned as one of the most important drivers of geopolitical imaginations (Agnew 2006: 185). Valley of the WolvesIraq becomes a venue where these geopolitical imaginations based on religion make their way, albeit in a very critical way. At the core of these lines is the critique of the Bush administration's neoconservative foreign policy, especially its 'democratization' agenda, which, to some extent, draws from the teachings of the fundamentalist Christian right (Monten 2005: 126-130). It is also a well-known fact that some of these fundamentalist Christian groups link Christ's return to earth with the establishment of a Jewish state in Babylon (Zunes 2005: 76).

While Valley of the Wolves-Iraq portrays Christians as those who would go to war to make peace, Islam is portrayed as the religion of peace and perseverance. In other words, the viewer receives hints of Pax Islamica. Islam's message is disseminated through another character, Şeyh (Sheikh) Abdulrahman Halis Kerkuki, played by Ghassan Messoud. The Sheikh character in the movie is respected by every ethnic group, showing and suggesting that Islam can be a key to transcend ethnicity and nation, and thus the problems of the region. This transcending nature of the Sheikh bothers Sam Marshall, because while the Marshall character is trying to apply the divide and rule principle, the Sheikh is portrayed as using the 'pacify and unite' nature of Islam - an image that runs contrary to the way Islam is presented in Western media outlets. As a result, Valley of the Wolves-Iraq is scattered with scenes and dialogs indicative of this self-perceived Pax Islamica message. For example, the movie contains a scene where the Sheikh tells a wounded Iraqi who wants to fight Americans to stay calm and accept his fate. He then dissuades Leyla, who wants to avenge her husband and relatives, from becoming a suicide 
bomber, on the grounds that it 'means giving up the hope that God will save you, and killing the innocents' - thoughts which the Sheikh claims to be the 'sign of Satan.' Following this in another scene, which is very reminiscent of the capture and decapitation of the journalist Daniel Pearl, the Sheikh saves an American journalist from decapitation by insurgents, telling them 'by tormenting other people you are also becoming the servant of the tormentors. Are you going to do what the Prophet has not done?' In addition to these scenes, elsewhere in the movie Muslims are shown praying peacefully and worshipping God - almost mirror images to those disseminated though Western media outlets after 9/11.

Finally, the way that Kurds and their link to the Turkish nation are portrayed in Valley of the Wolves-Iraq is also noteworthy, as the movie divides the Kurdish people into two: 'good Kurds' and 'bad Kurds'. Needless to say, the 'bad Kurds' are those who are collaborating with the Americans in Northern Iraq, expelling the Turkomans and Arabs from their villages and thus reengineering the demography of the region. The viewer meets the 'bad Kurd' early in the movie when Alemdar and his friends first cross into Northern Iraq:

ABDULHEY: I don't see any red carpet.

POLAT: Don't worry. We will soon see the red .... yellow,.... green.

Polat Alemdar and his friends do not see that traditional Kurdish tricolor (yellow, red, and green) but immediately after this conversation, are stopped by Peshmerga patrols at a road-side checkpoint, who ask the purpose of Alemdar's and his friends' visit. Alemdar says, 'Trade,..... I trade human beings, I heard they are cheap here,' referencing the Kurdish collaboration with the United States. The movie is then filled with scenes of bad Kurds helping Marshall.

There are 'good Kurds' too. The dialog between Alemdar's two friends, Memati and Abdulhey, towards the end of the movie, just before the final showdown between Marshall and Alemdar, highlights one such point:

MEMATI: It is all because of the Kurds.

ABDULHEY: I am a Kurd too!

MEMATI: But you are different.

ABDULHEY: That is how everything starts, brother.

So, here the viewer is informed that Kurds who work for the good of the Turkish state/nation, like Abdulhey, are the good ones and those who collaborate with the enemy against the interests of the Turkish state/nation are the bad ones. Approaching interethnic relations in this Manichean way 
paradoxically challenges and reaffirms one of the most important and reiterating themes of Turkish cinema: the phenomenon of 'deep nation.' Robins and Aksoy (2000) argue that until the 1990s Turkish cinema was pressured to emphasize unity among Turks. Here Valley of the Wolves-Iraq goes beyond this deep nation in an intriguing manner. While it recognizes the Kurdish existence through dialogs in Kurdish inserted in the movie, the presence of a Kurdish character like Abdulhey shows that this recognition is only conditional, meaning that tolerance towards 'others' is only possible as long as he/ she is working for 'us.'

\section{Conclusion}

The big fuss about Valley of the Wolves-Iraq is long over. But Valley of the Wolves continues as a TV series - again in a controversial manner. Alemdar Polat and his friends' first return to the TV screens was short lived. The sequel to Valley of the Wolves-Iraq, Valley of the Wolves-Terror, which had a storyline based on Turkey's 'terror' problem (read Kurdish separatism in southeastern Turkey), was shelved after one episode when the Turkish Radio-TV Higher Council (RTÜK) asked for the series to be suspended. The fans of the series were so angry that the head of the RTÜK received death threats causing him to ask for police protection (Sazak 2007). Rechristened Valley of the WolvesAmbush, the series continued. The fans were pleased and so were the producers of the series, who continue to be inspired by the real-life events taking place in Turkey.

Amidst the controversy and criticism, the movie and the series have made an important mark (I do not mean achievement by any means) in the history of Turkish popular culture. As this article argues, watching and writing on Valley of the Wolves-Iraq are worthwhile for several reasons. First, the movie is one of the interesting cases where cinema is used as a tool (maybe a weapon in this case) to reverse hegemonic geopolitical representations. This time it is the Turks who come up with representations of world events. Second, Valley of the Wolves-Iraq is rich in terms of reversed geopolitical representations or put differently, probably one of the best cases of anti-geopolitics. And because the movie was very popular, it can be argued that Valley of the Wolves-Iraq reflects or reaffirms the perceptions that Turks hold these days. These geopolitical representations are related to the way Turks envision themselves, their country's and other countries' place in the new global (dis)order, the issues that they perceive as a threat or danger, their yearnings and longings.

Jeopolitik (geopolitics) is an important term for Turks and Turkey. School children from an early age learn that Turkey is a geopolitically important 
country and that, as a result, its 'internal and external enemies' want to destabilize Turkey. Turkey, in other words, suffers from a 'perennial insecurity complex' (Aydın 2003: 163), and this 'insecurity complex' was until recently generated and regenerated by the Turkish state. Starting in the 1940s, first military and then civilian actors of statecraft picked up the term 'geopolitics' and formulated danger and threat perceptions of a nation and remained the sole authority to do so for many years (Bilgin 2007). In today's Turkey, however, the state is no longer alone. In the past few years, with the developments in mass media, other alternatives have emerged to challenge, but in most cases support the state's geopolitical representations. Valley of the Wolves-Iraq is a case in point; it is technically created by forces outside the state, yet one can find representations that mostly confirm the official ones.

Among these representations in Valley of the Wolves-Iraq, the most important ones are the favorable representations of the Turkish past and Islam. In defiance of hegemonic representations that for years projected the Turkish past and Islam from a very negative point of view, Valley of the Wolves-Iraq presents, literally, a virtual Pax Turca and Pax Islamica, showing Turks, Ottoman heritage and Islam as sources of stability and order in the Middle East. While there is also some critique of modern-day Turkey, much of the movie is a critique of the American Empire and its presence in the Middle East.

Overall, Valley of the Wolves-Iraq presents good news and bad news. The good news is that James Bond and Rambo have a new friend - Polat Alemdar - in charting geopolitical representations. The bad news is that Alemdar charts and will continue to chart these representations at the expense of further solidifying the apparent self/other distinctions and the insecurity complex in Turkey, just as his friends Bond and Rambo have, so far, done in the West.

\section{References}

Agence France Press (2006). German Political, Jewish Leaders Condemn Turkish Movie, February 20.

Agnew, John (2006). Religion and Geopolitics. Geopolitics, 11(2): 183-191.

Aydın, Mustafa (2003). Securitization of History and Geography: Understanding of Security in Turkey. Southeast European and Black Sea Studies, 3(2): 163-184.

Baran, Zeyno (2006). Patriot Games. The National Interest, 83: 134-138.

Bağrıaçık, Çiğdem, (2006). Ne Musevi ne de ABD Düşmanıyız. Milliyet, March 3.

Başlamış, Cenk (2006). Şiddete Karşılar Ama Polat’a Değil. Milliyet, August 19.

Bilgin, Pinar (2007). Only Strong States Can Survive in Turkey's Geography: The Uses of 'Geopolitical Truths' in Turkey. Political Geography, 26(7): 740-756.

Birch, Nicholas (2006). Audiences Cheer Film's Anti-US Message. The Washington Times, 15 February. 
Çalabakan, Şenol (2006). Almanya Kurtlar Vadisi’ni Tartışıyor. Milliyet, February 20.

Çalabakan, Şenol, Saadet Oruç and Mehmet Çiftçi (2006). Le Monde: Çuvalın Rövanşı Filmde Alınd. Milliyet, February 22.

Campbell, David (2003). Cultural Governance and Pictorial Resistance: Reflections on the Imaging of War. Review of International Studies, 29(1): 57-73.

Cheviron, Nicholas (2006). Wounded Pride Inspires Turkey's First Blockbuster. The Australian, February 8.

Çiftçi, Mehmet (2006). Güney Amerika’da Kurtlar Vadisi Heyecanı. Milliyet, February 24.

Coşkun, Bekir (2006). Filmleştik.... Hürriyet, February 11.

Crampton, Andrew and Marcus Power (2005). Frames of Reference on the Geopolitical Stage: Saving Private Ryan and the Second World War/Second Gulf War Intertext. Geopolitics, 10(2): 244-265.

Dittmer, Jason (2005). Captain America’s Empire: Reflections on Identity, Popular Culture and Post 9/11 Geopolitics. Annals of the Association of American Geographers, 95(3): 626-643.

Dodds, Klaus (2000). Geopolitics in a Changing World. Harlow: Prentice Hall/Pearson Education Limited.

Dodds, Klaus (2003). Licensed to Stereotype: Popular Geopolitics, James Bond and the Spectre of Balkanism. Geopolitics, 8(2): 125-156.

Edwardson, Ryan. (2005). The Many Lives of Captain Canuck: Nationalism, Culture and the Creation of a Canadian Comic Book Superhero. Journal of Popular Culture, 37(2): 184201.

Erdoğan, İrfan (2006). Kurtlar Vadisi Irak: Eski-Göçebe Kabil' in Yeni Emperyalist Habil'den Öç Alş̧ı. İletişim Kuram ve Araşttrma Dergisi, 22: 71-136.

Erol Işık, Nuran (2006). Milliyetçilik, Popüler Kültür ve 'Kurtlar Vadisi. Doğu-Batı, 9(38): 227247.

Geraghty, Jim. (2006). Anti-American Trash. The New York Sun, February 8.

Germany-OSC Report (2006). German Officials Condemn Ankara's Alleged Endorsement of Turkish Movie, February 23.

Gültekin, Zeynep. (2006). Irak'dan Önce: Kurtlar Vadisi Dizisi. İletiz̧im Kuram ve Araștrma Dergisi, 22: 9-36.

Haber X (2006). Kurtlar Vadisinden Erdoğan’a Özel Gösterim...., January 25.

Hasan, Aydın (2006). Polat Lider Gibiydi! Milliyet, February 4.

Howard, Michael and Suzanne Goldenberg. (2003). US Arrest of Soldiers Infuriates Turkey. The Guardian, July 8.

Hürriyet (2006). ABD Kongresi'nde Kurtlar Vadisi Irak Filmi Tartışıldı, March 24.

Internet Haber (2008). Kurtlar Vadisi Koltuktan Etti. Internet Haber website [Online]. Available: http://www.internethaber.com/news_detail.php?id=132306\&interstitial=true.

Kurlantzick, Joshua (2005). The Decline of American Soft Power. Current History, 686: 419425.

Members of Hizb ut-Tahrir (2006). Whilst Turkish Government Looks West, Its People Look to Islam. Hizb ut-Tahrir Official Website. Available: http://www.hizb.org.uk/opinions/index .php?id=3012_0_50_10_M132.

Milliyet (2006). Türkiye-ABD’nin Hıçkırması: Kurtlar Vadisi Irak ve Hamas. April 19.

Milliyet. (2006). Kurtlar Vadisi Irak 1 Ayda Gora’nın Rekorunu Kırdı. March 7.

Monten, Jonathan (2005). The Roots of the Bush Doctrine: Power, Nationalism, and Democracy Promotion in US Strategy. International Security, 29(4): 112-156.

Murray, Ben (2006). Troops to Avoid Turkish Film. Stars and Stripes, February 7.

Musa, Sudia (2006). Anti-Americanism Wins at the Turkish Box Office. ABC News [Online]. Available: http://abcnews.go.com/International/print?id=1617161.

Nye, Joseph, S (2004). Soft Power: The Means to Success in World Politics. New York: Public Affairs. 
O’Tuathail, Gearoid (1996). Critical Geopolitics. London: Routledge.

O'Tuathail, Gearoid (2005). The Frustration of Geopolitics and the Pleasures of War: Behind the Enemy Lines and American Geopolitical Culture. Geopolitics, 10(2): 356-377.

Özakman, Turgut (2005). Şu Çılgın Türkler. Istanbul: Bilgi Yayınevi.

Power, Marcus and Andrew Crampton (2005). Reel Geopolitics: Cinematographing Political Space. Geopolitics 10(2): 193-203.

Rainsford, Sarah (2006). Turks Rush to Embrace Anti-US Film. BBC News, February 10.

Robins, Kevin and Asu Aksoy (2000). Deep Nation: The National Question and Turkish Cinema Culture. In Hjort, Mette and Scott Mackenzie (Eds.), Cinema and Nation, pp. 203-221. London and New York: Routledge.

Routledge, Paul (1998). Introduction. In O'Tuathail, Gearoid et al. (eds.), The Geopolitics Reader, pp. 245-255. London and New York: Routledge.

Sağlam, Tülay (2006). Kurtlar Vadisi'nde Yankılanan Sesler. NTV MSNBC website. Available: http://www.ntvmsnbc.com/print.asp?pid=365164.

Sazak, Derya (2007). Kurtlar Vadisi Terör Çekilirken Uyardık. Milliyet, February 26.

Schlussel, Debbie (2006). Gary Busey's Blood Libel. Front Page Magazine [Online], February 6. Available: http://frontpagemagazine.com/Articles/Read.aspx?GUID=911F1BA9-E243488C-9014-7ACA3C6D6F95

Schogol, Jeff (2006). US Official Shrug Off Fictional Turkish Movie About Iraq. Stars and Stripes, (European Edition). February 23.

Sharp, Joanne P (1998). Reel Geographers of the New World Order: Patriotism, Masculinity and Geopolitics in Post-Cold War American Movies. In O’Tuathail, Gearoid and Dalby, Simon, (eds.), Rethinking Geopolitics, pp. 152-169. London: Routledge.

Tugend, Tom (2006). The Nefarious Parts We Play. Jerusalem Post [Online], February 15. Available: www.jpost.com/servlet/Satellite?cid=1139395417918\&pagename=JPost\%2FJP Article\%2FShowFull

Turk Rus (2006). 'Rus TV'si 'Kurtlar Vadisine Özel Ekip Yolladi', March 3.

Turkish Daily News (2006). US Commander Critical of Movie, Says Ties With Turkey Excellent, February 10.

Turna, Burak and Orkun Uçar (2004). Metal Firtına. Istanbul: Timaş Yayınları.

Vatan (2006). Ögrenciler ÖSS'den Korkuyor, September 23.

Vick, Karl (2006). Two Allies, Two Angles. The Washington Post, February 14.

Yanık, Lerna K (2008). 'Those Crazy Turks' That Got Caught in the 'Metal Storm': Nationalism in Turkey's Best Seller Lists. Robert Schuman Center for Advanced Studies, European University Institute Working Paper Series, February.

Yaşın, Cem (2006). Kurtlar Vadisi Irak Filminin Bilişsel Yapısı. İletişim Kuram ve Araştırma Dergisi, 22: 157-181.

Zaman (2006). Gül: Kurtlar Vadisi Ilişileri Etkilemez, 5 February.

Zunes, Stephen (2005). The Influence of Christian Right in US Middle East Policy. Middle East Policy, 12(2): 73-78. 